\title{
PENGARUH TEKNIK RELAKSASI HAND MASSAGE TERHADAP NYERI PADA PASIEN KANKER PAYUDARA DI YAYASAN KANKER INDONESIA SURABAYA
}

\author{
Puput Nur Fadilah, Puji Astuti, Wesiana Heris Santy \\ Fakultas Keperawatan dan Kebidanan \\ Universitas Nahdatul Ulama Surabaya Jl. Smea 57 Surabaya \\ Email:puji@unusa.ac.id
}

\begin{abstract}
Pain is a complaint which often happens to patients diagnosed with Cancer. Patients with breast cancer will feel pain when cancerous cells enlarge, wounds occur, and if metastasis happens. One of the simple ways to decrease the pain is to use hand massage relaxation technique. Therefore, this research was purposed to find out the effect of hand massage toward pain felt by patients with breast cancer. The research applied pre-experiment one group pre-post design. The population involved the patients with breast cancer experiencing pain. 11 respondents were chosen as the samples by using the probability sampling in which simple random sampling technique was applied in this research. The data were analyzed by using paired t-test. The result of research showed that before applying hand massage, the pain level was 5.09 on average, whereas the average pain level after applying hand massage was 3.09. It showed the difference on the pain level before and after applying hand massage. Furthermore, the result of research by using paired t-test showed that $\mathrm{p}$ value $=0.000$ and $\alpha<0.05$. The research concluded that hand massage relaxation technique brought an effect toward the pain experienced by the patients with breast cancer. Hence, the nurses in hospital should be able to do this relaxation technique to make their patients relaxed so that they can be independent in fulfilling their daily needs.
\end{abstract}

Keywords: breast cancer, pain, hand massage.

ABSTRAK: Penderita kanker payudara akan timbul rasa nyeri apabila sel kanker sudah membesar, timbul luka atau bila muncul metastase. Salah satu langkah sederhana untuk menurukan nyeri adalah dengan menggunakan teknik relaksasi hand massage. Penelitian ini bertujuan untuk mengetahui pengaruh hand massage terhadap nyeri pada pasien kanker payudara. Desain penelitian ini menggunakan Pra Experiment one group pre-post design. Populasi dalam penelitian ini adalah pasien kanker payudara mengalami nyeri sebesar 12 orang. Sampel sebesar 11 responden yang diambil secara probability sampling dengan teknik simple random sampling. Analisis statistik yang digunakan adalah paired t-test dengan tingkat kemaknaan $\alpha=0,05$. Hasil penelitian menunjukkan bahwa rata-rata tingkat nyeri responden sebelum diberikan teknik relaksasi hand massage adalah 5.09, sedangkan rata-rata tingkat nyeri responden sesudah diberikan teknik relaksasi hand massage adalah 3.09. Dapat dilihat bahwa ada perbedaan tingkat nyeri antara sebelum dan sesudah diberikan teknik relaksasi hand massage. Hasil penelitian dengan menggunakan uji paired t-test adalah $\rho$ value $=0.000$ dengan nilai $\alpha<0.05$. Simpulan dari penelitian ini adalah ada pengaruh pemberian teknik relaksasi hand massage terhadap nyeri pada pasien kanker payudara. Maka dari itu perlu adanya 
kerjasama antara perawat dengan keluarga pasien, sehingga pihak keluarga dapat melakukan hand massage untuk mengurangi nyeri pasien.

Kata kunci: kanker payudara, nyeri, hand massage

\section{PENDAHULUAN}

Kanker payudara adalah jenis kanker yang paling umum diderita oleh kaum wanita. Wanita dapat bertahan hidup bertahun-tahun setelah didiagnosis kanker payudara, namun penyakit ini tidak dapat disembuhkan jika ditemukan pada stadium lanjut. Kanker payudara terjadi karena terganggunya sistem pertumbuhan sel di dalam jaringan payudara. Sel kanker dapat menyerang dan merusak jaringan sekitar (Zora et al, 2011). Pada penderita kanker payudara akan timbul rasa nyeri apabila sel kanker sudah membesar, sudah timbul luka atau bila sudah muncul metastase ke tulang-tulang (Maysaroh, 2013).

Nyeri pada pasien kanker merupakan suatu fenomena subjektif yang merupakan gabungan antara faktor fisik dan non fisik. Nyeri dapat berasal dari berbagai bagian tubuh ataupun sebagai akibat dari terapi dan prosedur yang dilakukan termasuk operasi, kemoterapi dan radioterapi. Nyeri yang dialami oleh penderita kanker payudara diakibatkan pengaruh langsung terhadap organ yang terkena dan pengaruh langsung terhadap jaringan lunak yang terkena (Rasjidi, 2010).

Dari data awal yang diperoleh jumlah penderita kanker payudara di Yayasan Kanker Indonesia Surabaya pada tahun 2012 terdapat 32 orang, sedangkan pada tahun 2013 terdapat 43 orang. Data yang diperoleh dari Dinas Kesehatan, distribusi penyakit kanker di Jawa Timur pada tahun 2010 terdapat 1253 orang yang mengidap kanker payudara. Pada tahun 2011 terdapat 1527 orang yang menderita kanker payudara. Laporan ini menunjukkan bahwa ada peningkatan jumlah penderita kanker payudara tiap tahunnya di provinsi Jawa Timur, (Dinas Kesehatan Provinsi, 2012).

Pasien kanker payudara yang mengalami nyeri, biasanya di rumah sakit hanya diberikan terapi secara farmakologis tanpa ada intervensi khusus dalam perawatannya, dengan begitu bisa dikatakan bahwa intervensi mandiri perawat dalam mengatasi nyeri belum adekuat. Perawat masih mengutamakan tindakan kolaboratif dengan pemberian analgesik. Obat analgesik jenis NSAID (Non-Steroid Anti Inflamasi Drugs) masih merupakan kunci utama dan yang biasa digunakan dalam menangani nyeri kanker.

Hand massage merupakan langkah yang paling efektif untuk meningkatkan relaksasi dan dijadikan sebagai terapi paliatif (Kolcaba et al, 2004). Hand massage artinya memberikan stimulasi di bawah jaringan kulit dengan memberikan sentuhan dan tekanan yang lembut untuk memberikan rasa nyaman (Ackley et al, 2008). Hand massage diberikan untuk menimbulkan efek yang menyenangkan bagi pasien kanker payudara. Apabila pasien kanker payudara mempersepsikan sentuhan sebagai stimulus untuk rileks, kemudian akan muncul respon relaksasi. Relaksasi juga dapat mengurangi rasa cemas akibat nyeri, sehingga dapat mencegah nyeri bertambah berat. Hand massage dapat menjadi pilihan untuk memberikan sensasi kenyamanan yang dapat 
meredakan ketegangan dan membuat pasien menjadi rileks akibat nyeri. Cara kerja dari masase ini menyebabkan terjadinya pelepasan endorfin, sehingga memblok transmisi stimulus nyeri (Potter \& Perry, 2005).

Teknik untuk melakukan hand massage dapat dilakukan dengan beberapa pendekatan, salah satu metode dilakukan adalah dengan memberikan tekanan lembut dan gesekan di seluruh telapak tangan klien dengan melibatkan gerakan melingkar kecil dengan menggunakan ujung jari atau ibu jari perawat dalam waktu 5-10 menit (Kolcaba et al, 2004). Upaya sentuhan yang lembut dapat memberikan kesenangan dan kenyamanan bagi pasien. Teknik ini sederhana dan mudah dilakukan, sehingga bisa di terapkan kepada siapapun yang mengalami rasa nyeri khususnya pada pasien kanker payudara. Pengaruh yang ditimbulkan dari hand massage adalah mengurangi ketegangan, meningkatkan relaksasi fisik dan psikologi. hand massage dapat membantu kemandirian klien dan keluarga dalam mengelola nyeri, khususnya bagi pasien yang tidak ingin mengatasi nyeri dengan menggunakan terapi farmakologis. Selain itu dalam pemberian hand massage tidak perlu menggunakan alat khusus yang membutuhkan biaya besar sehingga stimulus ini dapat diberikan pada klien dengan strata ekonomi apapun.

\section{METODE}

Penelitian ini dirancang dengan penelitia eksperimental (one group pre-post design), dengan tujuan untuk membuktikan pengaruh teknik relaksasi hand massage terhadap nyeri pada pasien kanker payudara.

Populasi penelitian ini adalah pasien kanker payudara mengalami nyeri dan berjenis kelamin perempuan di Yayasan Kanker Indonesia Surabaya dengan rata-rata 12 orang. Setelah dihitung dengan menggunakan rumus, didapatkan besar sampel 11 sampel.

Variabel independen dalam penelitian ini adalah pemberian teknik relaksasi hand massage. Variabel dependen dalam penelitian ini adalah tingkat nyeri pada pasien kanker payudara. Instrumen yang digunakan dalam variabel independen (pemberian teknik relaksasi hand massage) menggunakan SOP teknik hand massage. Instrumen yang digunakan dalam variabel dependen (tingkat nyeri pada pasien kanker payudara) menggunakan skala nyeri numerik 010 dari Potter \& Perry (2005).

Peneltian ini dilakukan dengan rekomendasi dari program studi Sarjana Keperawatan Fakultas ilmu kesehatan Unusa dan izin dari ketua Yayasan Kanker Indonesia Surabaya. Tahapan dalam pengumpulan data yang telah dilakukan peneliti adalah: (1). Tahap administrasi yaitu peneliti mendapatkan rekomendasi dari Unusa yang disampaikan ke institusi tempat penelitian. Responden yang ditetapkan berdasarkan kriteria penelitian. (2). Tahap seleksi yaitu melakuka pendekatan pada pasien, menjelaskan kepada responden tentang tujuan dan manfaat penelitian, kemudian responden yang bersedia diminta untuk menandatangani lembar persetujuan responden. (3). Tahap pelaksanaan yaitu responden yang sudah menandatangani lembar persetujuan diukur tingkat nyerinya dengan mengisi kuisioner yaitu skala intensitas nyeri numerik (NRS) 0-10, setelah itu responden diberikan tindakan hand massage dengan dosis 10 menit dalam sehari selama 6 hari berturut-turut, dan yang terakhir 
responden diukur kembali tingkat nyerinya pada hari ke-6 dengan mengisi kuisioner yaitu skala intensitas nyeri numerik (NRS).

\section{HASIL \& PEMBAHASAN}

\section{a. Hasil}

Tabel 1 Distribusi responden berdasarkan usia di Yayasan Kanker Indonesia Surabaya bulan Maret 2014

\begin{tabular}{ccccccc}
\hline & $\mathrm{N}$ & Min & Mak & Mean & SD & $\begin{array}{c}95 \% \\
\text { CI }\end{array}$ \\
& & & & & \\
\hline Usia & & & & & & \\
resp & 11 & 39.00 & 73.00 & 55.73 & 9.47 & 1.58 \\
onde & & & & & & 2.42 \\
n & & & & & & \\
\end{tabular}

Tabel 2 Distribusi responden berdasarkan kebudayaan di Yayasan Kanker Indonesia Surabaya bulan Maret 2014

\begin{tabular}{ccc}
\hline Kebudayaan & Frekuensi & Persentase \\
\hline Bali & 1 & 9.1 \\
Jawa & 9 & 81.8 \\
Madura & 1 & 9.1 \\
\hline Total & 11 & 100 \\
\hline
\end{tabular}

Tabel 3 Distribusi tingkat nyeri sebelum tindakan (pre-test) hand massage di Yayasan Kanker Indonesia Surabaya pada bulan Maret 2014

\begin{tabular}{ccccccc}
\hline & N & Min & Mak & Mean & SD & $\begin{array}{c}95 \% \\
\text { CI } \\
\text { Lower } \\
\text { Upper }\end{array}$ \\
\hline $\begin{array}{c}\text { Nyeri } \\
\text { pre-test }\end{array}$ & 11 & 2.00 & 7.00 & 5.09 & 1.58 & $\begin{array}{c}1.58 \\
2.42\end{array}$ \\
\hline
\end{tabular}

Tabel 4 Distribusi tingkat nyeri sesudah tindakan (post-test) hand massage di Yayasan Kanker Indonesia Surabaya pada bulan Maret 2014

\begin{tabular}{ccccccc}
\hline & $\mathrm{N}$ & Min & Mak & Mean & SD & $\begin{array}{c}95 \% \\
\text { CI } \\
\text { Lower } \\
\text { Upper }\end{array}$ \\
\hline $\begin{array}{c}\text { Nyeri } \\
\text { post-test }\end{array}$ & 11 & 1.00 & 6.00 & 3.09 & 1.51 & $\begin{array}{c}1.58 \\
2.42\end{array}$ \\
\hline
\end{tabular}

Tabel 5 Distribusi perbedaan tingkat nyeri sebelum dan sesudah tindakan hand massage di Yayasan Kanker Indonesia Surabaya pada bulan Maret 2014

\begin{tabular}{cccccccc}
$\begin{array}{c}\text { Nye } \\
\text { ri }\end{array}$ & $\mathrm{N}$ & $\begin{array}{c}\mathrm{Mi} \\
\mathrm{n}\end{array}$ & Max & $\begin{array}{c}\text { Me } \\
\text { an }\end{array}$ & $\begin{array}{c}\mathrm{S} \\
\mathrm{D}\end{array}$ & $\mathrm{t}$ & $\begin{array}{c}\rho \\
\text { value }\end{array}$ \\
\hline Pre & 1 & 2.0 & 7.00 & 5.0 & 1 & 10. & $.000^{*}$ \\
\cline { 4 - 6 }
\end{tabular}

\begin{tabular}{|c|c|c|c|c|c|}
\hline $\begin{array}{c}- \\
\text { test }\end{array}$ & 1 & 0 & & 9 & $\begin{array}{ll} & 49 \\
5 & \\
8 & \\
\end{array}$ \\
\hline $\begin{array}{c}\text { Pos } \\
t \text { - } \\
\text { test }\end{array}$ & $\begin{array}{l}1 \\
1\end{array}$ & & 6.00 & & $\begin{array}{l}1 \\
. \\
5 \\
1\end{array}$ \\
\hline
\end{tabular}

\section{b. Pembahasan}

Hasil penelitian menunjukkan bahwa sebelum diberikan teknik relaksasi hand massage pasien kanker payudara memiliki respon nyeri ratarata 5.09. Dan setelah diberikan teknik relaksasi hand massage pasien payudara mengalami penurunan tingkat nyeri dengan rata-rata 3.09. Hasil uji didapatkan $(\rho=0,000)$, serta ada pengaruh teknik relaksasi hand massage terhadap nyeri pada pasien kanker payudara.

Hand massage merupakan salah satu teknik relaksasi untuk menurunkan nyeri dengan cara memberikan sentuhan dan tekanan yang lembut dibawah jaringan kulit. Efek relaksasi yang ditimbulkan dari hand massage dapat mengurangi rasa nyeri yang dirasakan oleh pasien, sehingga dapat mencegah nyeri bertambah berat. Selain itu, sebelum melakukan tindakan hand massage sebaiknya menghilangkan sumbersumber suara yang berisik di lingkungan, menyapa klien dengan ramah dan rasa penuh perhatian. Hal ini dapat membuat klien merasa diperhatikan. Sehingga rasa nyaman timbul dan nyeri menjadi berkurang, namun setiap responden yang dipijat mengungkapkan ekspresi dan letak kenyamanan yang berbeda-beda.

Hand massage artinya memberikan stimulasi dibawah jaringan kulit dengan memberikan sentuhan dan tekanan yang lembut untuk memberikan rasa nyaman (Ackley et al, 2008). Stimulasi kulit akan merangsang serat-serat non- 
nosiseptif yang berdiameter besar untuk menutup gerbang bagi seratserat berdiameter kecil yang menghantarkan nyeri sehingga dapat dikurangi. Dihipotesiskan bahwa stimulasi kulit juga dapat menyebabkan tubuh mengeluarkan endorphin dan neurotransmitter lain yang menghambat nyeri (Price et al, 2012). Teknik dalam melakukan hand massage lebih ditekakan pada masase di punggung tangan dan pergelangan tangan, karena di dua tempat tersebut terdapat titik meridian jantung yang melewati dada. Titik ini membantu dalam pelepasan endorfin ke dalam tubuh yang dapat memperlancar peredaran darah dan menutrisi sel, sehingga menimbulkan efek relaksasi (Fengge, 2012).

Hand massage merupakan salah satu bentuk teknik relaksasi yang dapat memberikan kenyamanan bagi klien, sehingga dapat mengurangi rasa nyeri yang dirasakan oleh klien (Barbara, 2010).

\section{KESIMPULAN}

Tingkat nyeri pasien kanker payudara sebelum diberikan teknik relaksasi hand massage memiliki ratarata 5.09. Setelah diberikan teknik relaksasi hand massage pasien kanker payudara mengalami penurunan tingkat nyeri dengan rata-rata 3.09. Teknik relaksasi hand massage dapat menurunkan tingkat nyeri pada pasien kanker payudara.

\section{Saran}

Diharapkan adanya pemberian teknik relaksasi hand massage sebagai upaya untuk membantu pasien kanker payudara menguragi nyeri yang dirasakan. Dan perlu melibatkan peran keluarga sebagai perawatan pasien kanker payudara setelah keluar dari rumah sakit (di rumah).

\section{DAFTAR PUSTAKA}

Arikunto, S. (2010). Prosedur Penelitian Suatu Pendekatan Praktik. Jakarta, RinekaCipta.

Ackley, Ladwig, Swan, Tucker (2008). Evidence-Based Nursing Care Guidelines : MedicalSurgical Intervention. Amerika, Mosby.

Baradero, M., Dayrit, M. W., Siswadi Y. (2007). Klien Kanker: Asuhan Keperawatan. Jakarta, EGC.

Barbara, Kunz K. (2012). Reflexiology Health at Your Finger. London, Dorling Kindersley Limited.

Fengge, Antoni. (2012). Terapi Akupresur: Manfaat \& Teknik Pengobatan. Yogyakarta, Crop Circle Corp

Ghofar, Abdul. (2009). Cara Mudah Mengenal \& Mengobati Kanker. Jogjakarta, Flamingo.

Kolcaba, K., Dowd, T., Steiner R., Mitzel, A. (2004). Efficacy of Hand Massage for Enhacing the Comfort of Hospice Patients. Journal of Hospice and Palliative Nursing. Vol. 6, No. 2

Maysaroh, Hanik. (2013). Kanker Pada Perempuan \& Penyembuhannya. Klaten, Trimedia Pustaka.

Melissa S, Luwia MHA. (2004). Problematik \& Perawatan Payudara. Jakarta, Kawan Pustaka.

Mindi, M., Edge, V. (2002). Women's Health Care. United States of Amerika, Mosby-Yearbook.

Mulyani, N. S. (2013). Kanker Payudara \& PMS pada Kehamilan. Yogyakarta, Nuha Medika.

Notoatmodjo, Soekidjo. (2012). Metodologi Penelitian Kesehatan. Jakarta, Rineka Cipta.

Nursalam. (2011). Konsep dan Penerapan Metodologi Penelitian 
Ilmu Keperawatan: Pedoman Skripsi, Tesis dan Instrument Penelitian Keperawatan. Jakarta, Salemba Medika.

Nugroho, Taufan. (2011). ASI dan Tumor Payudara. Yogyakarta, Nuha Medika.

Potter \& Perry. (2005). Buku Ajar Fundamental Keperawatan, Edisi 4. Jakarta, EGC.

Pinandita, I., Purwanti, E., Utoyo, B. (2012). Pengaruh Teknik Relaksasi Genggam Jari Terhadap Penurunan Intensitas Nyeri pada Pasien Post Operasi Laparatomi. Jurnal Ilmiah Kesehatan Keperawatan. Vol. 8, No.1

Prasetyo, Sigit Nian. (2010). Konsep dan Proses Keperawatan Nyeri. Edisi 1. Yogyakarta, Graha Ilmu Price, Sylvia Anderson., Lorraine, Mc. Carty Wilson. (2005). Patofisiologi: Konsep Klinis Proses-Proses Penyakit. Edisi 6. Jakarta, EGC

Rasjidi, Imam. (2010). Perawatan Paliatif Suportif dan Bebas Nyeri pada Kanker. Jakarta, Sagung Seto.

Sukardja, I Dewa Gede. (2000). Onkologi Klinik. Edisi 2. Surabaya, AUP

Tamsuri, Anas. (2006). Konsep \& Penatalaksanaan Nyeri. Jakarta, EGC.

Wasis. (2008). Pedoman Riset Praktis Untuk Profesi Perawat. Jakarta, EGC.

Wiyoto, B.T. (2012). Remedial Massage. Edisi 1. Yogyakarta, Nuha Medika

Zora, K., Brown Karl, K., Boatman, M.D. (2009). One Hundred Questions \& Answers About Breast Cancer. Edisi 3. Canada, LLC.

Anonim. (2012). Kegiatan

Pengendalian Kanker di Jawa Timur, http: //www.dinkes.jatimprov.go.id.

diakses pada 7 Februari 2012 pukul 17:49 